\section{Breast Core}

Breast Care 2006;1:288

\title{
Focus: Prevention
}

\section{Editorials}

Review Articles
Chemoprevention: Pro

Paepke, S. (München)

Chemoprevention: Contra

Gnant, M. (Wien)

Prevention Trials in Women with Moderate Risk for Breast Cancer v. Minckwitz, G.; Gimeno, S.; Segura-Eicke, P.; Loibl, S. (Neu Isenburg)

The Role of Physical Activity in the Prevention and Rehabilitation of Breast Cancer Graf, C.; Brixius, K.; Baumann, F.; Ahr, A.; Schüle, K. (Köln)

Nutrition in Breast Cancer Prevention

Kührer, I. (Wien)

Breast Cancer: Psychological Prevention / Predisposition Hawighorst-Knapstein, S. (Mainz)

Follow-Up for Breast Cancer - the Patients' View

Stemmler, H.J.; Stieber, P.; Bauerfeind, I.; Hoffmann, V.; Heinemann, V. (München); Fasching, P.A.; Beckmann, M.W. (Erlangen); Glattes, M. (Düsseldorf); Goldmann-Posch, U. (Augsburg)

The Effect of a Cyclooxygenase-2 Inhibitor on Proliferating Activity in Breast Carcinoma: First Results Buxant, F.; Devreker, F.; Noël, J.C. (Brussels)

Peripheral Neuroectodermal Tumor (PNET) of the Breast - a 6-Year Follow-Up Thomas, A.; Blohmer, J. U.; Sezer, O.; Fischer, T.; Thiel, G.; Dietel, M.; Lichtenegger, W. (Berlin); Kümmel, S. (Essen)

A Case of Pyllodes Tumor with Focal Transition into Low-Grade Lymphangiosarcoma

Bachleitner-Hofmann, T.; Schoppmann, S. F.; Rudas, M.; Wiener, H.; Dubsky, P.; Blaha, P.; Sporn, E.; Panhofer, P.; Fitzal, F.; Kandioler, D.; Gnant, M.; Jakesz, R. (Wien) 